\title{
INTERFACES ARTIFICIAIS E INTERPRETAÇÃO JUDICIAL: O PROBLEMA DO USO DA INTELIGÊNCIA ARTIFICIAL E DA METODOLOGIA FUZZY NA APLICAÇÃO DO DIREITO
}

\author{
ARTIFICIAL INTERFACES AND JUDICIAL REVIEW: THE PROBLEM OF THE USE OF \\ ARTIFICIAL INTELLIGENCE AND THE FUZZY METHODOLOGY IN THE APPLICATION \\ OF THE LAW
}

Fernando de Brito Alves

\begin{abstract}
Doutor em Direito pela Instituição Toledo de Ensino - ITE. Mestre em Ciência Jurídica pela Universidade Estadual do Norte do Paraná - UENP. Graduado em Filosofia pela Universidade do Sagrado Coração e Graduado em Direito pela Universidade Estadual do Norte do Paraná - UENP. Assessor Jurídico eProfessor adjunto da UENP. Coordenadordo Programa de Pós-graduação em Ciência Jurídica e Professor das Faculdades Integradas de Ourinhos. E-mail: fernandobrito@uenp.edu.br
\end{abstract}

Elídia Aparecida de Andrade Corrêa

Doutoranda em Ciência Jurídica pela Universidade Estadual do Norte do Paraná - UENP. Mestre em Ciência Jurídica pela Faculdade Estadual de Direito do Norte Pioneiro; Graduada em Direito pela Instituição Toledo de Ensino; Juíza Federal - Justiça Federal da Terceira Região e Coordenadora da subseção de Ourinhos - Justiça Federal da Terceira Região. E-mail: eacorrea@trf3.jus.br

Recebido em: 06/06/2018 Aprovado em: 17/04/2019

RESUMO: Na aplicação de regras e normas jurídicas pelo Poder Judiciário brasileiro, atualmente é exigida uma atuação mais objetiva, inclusive mediante a utilização de métodos lógicos computacionais, interfaces artificiais e precedentes judiciais com aplicação obrigatória, o que, não respeitados determinados limites, pode levar à injustiça do caso concreto. Para a verificação dessa hipótese, o presente artigo busca refletir sobre a atuação do Poder Judiciário nacional frente à contemporânea sistematização do processo judicial e novas tecnologias, aplicando-se as regras e princípios constitucionais da dignidade da pessoa humana, legalidade, publicidade, eficiência, bem como a proporcionalidade e a razoabilidade, como normas processuais concretas e prevalentes, ainda que o conteúdo jurídico venha informado por conceitos indeterminados ou "conforme" o caminho histórico percorrido ou a percorrer. A pesquisa apresentada neste artigo se utiliza dos métodos descritivo, qualitativo, bibliográfico e dedutivo. Ao final, serão apresentadas as conclusões com ênfase nos principais aspectos encontrados ao longo da pesquisa.

Palavras-chave: Dignidade da Pessoa Humana; Judiciário Brasileiro; Inteligência Artificial; Interpretação; Metodologia Fuzzy. 


\begin{abstract}
In the application of legal rules and norms by the Brazilian Judiciary, a more objective action is now required, including through the use of computational logic methods, artificial interfaces and judicial precedents with mandatory application, which, given certain limits, can lead to injustice in specifics cases. In order to verify this hypothesis, the present article seeks to reflect on the performance of the Brazilian Judiciary in relation to the contemporary systematization of judicial process and new technologies, applying the constitutional rules and principles of human dignity, legality, publicity, efficiency, well such as proportionality and reasonableness, as concrete and prevalent procedural norms, even if the legal content is informed by indeterminate concepts or "according" to the historical path covered or to be followed. The research presented in this article uses the descriptive, qualitative, bibliographic and deductive methods. At the end, the conclusions will be presented with emphasis on the main aspects found throughout the research.
\end{abstract}

Keywords: Dignity of Human Person; Brazilian Judiciary; Artificial Intelligence; Interpretation; Fuzzy Methodology.

SUMÁRIO: Introdução; 1 Positivismo Constitucional na Contemporaneidade Brasileira; 2 Inteligência Artificial e Metodologia Fuzzy na Atuação Judicial; 3 Precedentes Obrigatórios e Interpretação Judicial; Conclusão; Referências.

\title{
INTRODUÇÃO
}

Críticas reiteradas são feitas quanto à falta de racionalidade jurídica nas decisões do Poder Judiciário, em especial as proferidas pelo Supremo Tribunal Federal e pelo Superior Tribunal de Justiça. Parte das críticas aponta para o fato das decisões de tais Cortes utilizarem argumentos não jurídicos ou mesmo em incorrerem em absoluta ausência de fundamentação jurídica, verificando-se no julgado uma preocupação maior quanto aos seus resultados, a redundar inclusive na elaboração de uma "nova norma jurídica" para a resolução de casos futuros, ao contrário de oferecer a completude da solução concreta com a apresentação de uma mais cuidadosa exegese da lei e do direito aplicado.

Alguns destes julgados judiciais decorrem de certo enfrentamento entre o Poder Judiciário e os demais poderes do Estado, especialmente com o Poder legislativo, o que faz com que alguns críticos aleguem a usurpação da atribuição constitucional e violação do princípio da separação de poderes ao pronunciarem tais decisões.

Em contrapartida, quando os Poderes Legislativo e Executivo não funcionam bem, e leis são editadas ante a pressão de lobbies de determinados segmentos da sociedade e da economia, tanto o direito produzido perde parcialmente sua legitimidade, por não corresponder aos anseios da sociedade e da democracia, como também os poderes do Estado perdem parte de sua legitimidade histórica.

No embate entre as forças políticas, econômicas e jurídicas, as consequências são graves para a democracia, pois acabam atingindo as políticas públicas a serem implementadas pelo Poder Executivo e trazem uma massa de demandas para o Poder Judiciário que não existiria caso os poderes estatais funcionassem bem.

O Poder Judiciário, que somente em casos de violações legais e constitucionais deveria intervir na execução de políticas públicas, vem sendo demandado incessantemente, obrigando seus membros a decidirem - inclusive repetidamente - tamanha massa de demandas. E tal atuação gera, por óbvio, uma situação de falta de segurança jurídica para os jurisdicionados. 
Nesse ambiente de malversação dos princípios constitucionais que devem balizar a atuação de qualquer dos Poderes da União, elege-se o Poder Judiciário como uma alternativa para a resolução de conflitos de natureza social. Esse desvirtuamento da atuação constitucional do legislativo e do executivo faz com que se modifique o local de disputas, passando-se do plano político para o plano judicial, ocorrendo a judicialização de temas sociais e políticos, tornando a atuação do Poder Judiciário mais política que judicial.

Acrescente-se a tudo isso a circunstância de que a composição dos Tribunais não fica afeta estritamente ao Poder Judiciário, mas sofre forte ingerência do Poder Executivo (para não dizer dos próprios Partidos Políticos). De fato, a promoção a cargos de Desembargadores e Ministros dos Tribunais se dá pela indicação e nomeação do chefe do Poder Executivo, que vislumbra (em regra) nesse poder constitucional uma forma de controlar o Poder Judiciário.

Essa interferência do Poder Executivo na composição dos Tribunais tem um reflexo bastante pernicioso para a construção de uma racionalidade jurídica no Brasil, em especial quando ela se dá no Supremo Tribunal Federal, a quem cabe a guarda da Constituição.

Interessante observar que, quando a atuação do desembargador ou do ministro contraria o pretendido pela força política, consuma-me uma maior pressão político-partidária sobre os tribunais nacionais (com maior ênfase sobre os Tribunais Superiores), objetivando conformar as decisões jurisdicionais aos seus interesses, nem que para isso lancem mão de campanhas que visem desmoralizar o Poder Judiciário, reações com ênfase na desobediência às ordens judiciárias ou, ainda, a criação de projetos de lei que visem à intimidação dos seus membros.

Assim é que, com cerca de 109,1 milhões de ações em seu acervo, no ano de 2016, segundo dados informados pelo Conselho Nacional de Justiça - CNJ, com déficit estrutural e com um processo judicial eletrônico incipiente, vê-se que ao Poder Judiciário foi transferida a assunção do papel de curador da cidadania e da própria democracia, levando-o a proferir decisões divergentes em suas várias instâncias e sob a crítica de atuação decorrente de ativismo judicial.

Tal estado de coisas levou à alteração do Código de Processo Civil buscando a adoção de uma nova teoria atinente aos precedentes judiciais, sob o manto da obrigatoriedade para o julgamento de casos simétricos já julgados anteriormente.

Contudo, passados dois anos de vigência do atual CPC, ainda não se percebe efeitos positivos na atuação judicial, nem mesmo a aplicação efetiva dos chamados precedentes obrigatórios, haja vista que o cipoal jurisprudencial editado diuturnamente em nosso país mostra a nossa incapacidade de propiciar um tratamento igualitário e seguro para os conflitos levados a julgamento, tornando difícil o estabelecimento de uma racionalidade jurídica coerente.

As próprias Cortes superiores ignoram, em muitos casos, os julgados anteriores proferidos por ela própria, sem fundamentar devidamente a superação do entendimento, ou, ainda, não promovendo a necessária uniformização de sua jurisprudência, deixando o resultado final da demanda judicial no limbo da loteria, provocando, tais situações, a perda da confiança do jurisdicionado no Poder Judiciário.

É neste cenário de desvirtuamento constitucional que se tenta analisar a questão da interpretação judicial, dos precedentes obrigatórios e a adoção da inteligência artificial para melhorar a atuação jurisdicional frente à criação de uma racionalidade jurídica na aplicação do direito nacional para enfrentar o amplo cabedal de princípios, leis, doutrinas e correntes jurisprudenciais que compõem o quadro no Brasil, além das regras de aplicação das leis e a necessidade de sua integração e interpretação. E se, em face desse quadro atual, é possível uma análise qualitativa e quantitativa do direito com a utilização de novas tecnologias ou, até mesmo, se é possível adotar metodologias computacionais, como o que se dá pela utilização da metodologia fuzzy.

Para abordagem dos vários assuntos indicados, usaremos os métodos descritivo, qualitativo, bibliográfico (com base, principalmente, em livros, teses, artigos, legislação, sites e 
matérias jornalísticas) e dedutivo, pois eles se revelam mais compatíveis com os objetivos aqui propostos.

O artigo, além desta introdução, é formado por três partes discursivas e uma conclusão. A primeira parte aborda a questão do positivismo constitucional aplicado no ordenamento jurídico pátrio, em conformidade com a fase de desenvolvimento atual, além de traçar alguns paradoxos encontrados na atuação do Poder Judiciário nacional. Já a segunda parte se dispõe a tratar da possibilidade de aplicação judicial da lógica do campo da ciência da computação denominada metodologia fuzzy, além da aplicação das tecnologias para a criação de um juiz virtual em substituição ao judge human e sua racionalidade jurídica crítica. O terceiro tópico visa analisar a prevalência dos direitos fundamentais estampados na Constituição Federal sobre as normas jurídicas, entre elas os próprios precedentes obrigatórios. E, por fim, na conclusão, são descritos e avaliados os pontos centrais decorrentes dos fundamentos teóricos adotados nos vários aspectos abordados neste trabalho.

\section{POSITIVISMO CONSTITUCIONAL NA CONTEMPORANEIDADE BRASILEIRA}

No Brasil, em razão das críticas apresentadas ao Poder Judiciário, torna-se importante verificar como deve se dar o equilíbrio da atuação desse poder ante a obrigação de aplicar o direito multifacetado e o seu mister de ser o pacificador social por excelência diante de um acesso desenfreado ao Poder Judiciário ${ }^{1}$.

Uma questão deve ser de pronto apresentada no limiar deste texto: como deve ser distribuída a justiça por um Estado, onde os interesses do povo são suplantados pela corrupção e conchavos para perpetuação do poder e não da democracia?

Cambi (2009, p. 124) oferece uma resposta, a partir da atuação judicial:

[...] devendo a jurisdição, enquanto manifestação do poder estatal, servir de fonte de definição dos rumos da sociedade politicamente organizada. Estando o processo intimamente vinculado ao poder político, compete ao juiz suprir em sua atividade, as omissões do administrador e do legislador, bem como corrigir os rumos tomados por esses agentes de forma a contribuírem positivamente para a solução dos problemas sociais.

Nesse passo, não podemos olvidar que a democracia tem por objetivo dar maior liberdade a todos e para todos, na medida em que trabalha a favor da justiça, e propicia, em sua aplicação, a construção do estado Democrático de Direito. ${ }^{2}$

Nesse diapasão, para Garcia e Alves (2001, p. 70), os homens são unidos pelo direito e, consequentemente, se submetem a ele, que passa a representar uma forma de garantir os cidadãos contra os desmandos da Administração Pública, fato esse identificado como "a submissão do Estado ao direito". Aliás, para os autores ora em apreço, o Estado de Direito nada mais é que:

[...] o verdadeiro alicerce do positivismo jurídico, encontrando seu fundamento de validade na norma, sendo esta a fonte primária de sua existência e de todos os atos estatais. A esta concepção, no entanto, deve ser acrescido o elemento aglutinador dos valores e das aspirações que emanam do agrupamento, o que é reflexo da identificação do real detentor do poder: o povo. Com isto, integra-se o aspecto legal com os valores

\footnotetext{
${ }^{1}$ Denominado "uso predatório do sistema de justiça", conforme seminário realizado no Auditório do Superior Tribunal de Justiça em Brasília, em 21/05/2018.

${ }^{2}$ Para Alves (2014, p. 43), não é possível adotar a democracia deliberativa quando se conversa e se debate com quem tem fome. A democracia pressupõe igualdade, mas sem igualdade de condições não há possibilidade de debate. Ainda para o mesmo autor, democracia é um direito fundamental e como tal deve ser respeitado o espaço de dissenso.
}

Revista de Direito Brasileira | Florianópolis, SC | v. 23 | n. 9 | p. 5-27 |Mai./Ago. 2019 
que o antecedem e o direcionam, ensejando o surgimento do Estado democrático de direito.

Alves (2014, p. 57-58) afirma que muitas vezes a democracia, com a máxima de que a política é feita pela vontade da maioria do povo, pode gerar governos ditatoriais, pois a divinização da vontade da maioria transforma a democracia em um governo irracional e manipulável. A corroborar seu pensamento, o autor cita Boaventura de Souza Santos, para quem temos o direito de ser iguais quando nossa diferença nos inferioriza e temos direito de ser diferentes quando a nossa igualdade nos descaracteriza. Para o autor, ai está "a necessidade de uma igualdade que reconheça as diferenças; e de uma diferença que não produza, alimente ou reproduza as desigualdades" (ALVES, 2014, p. 57-58). O autor em comento afirma que o Poder Judiciário deve julgar conforme o direito, reafirmando a autonomia do direito em relação à política, pois apesar de caber ao Poder Judiciário o controle último, deve ser "um controle que se justifique pelo direito, a fim de dar uma resposta à sociedade, sempre conforme a Constituição e leis" (ALVES, 2014, p.58).

Consentâneo com estes entendimentos, HÖFFE (2005) afirma que a democracia não é apenas o caminho relativamente melhor, mas especialmente o mais seguro para a justiça concreta. Nela, os três poderes do Estado que a elege, devem primar para evitar tensões com o próprio conceito de justiça. ${ }^{3}$ A atuação deve ser centrada na efetivação dos objetivos sociais.

Tratando das Estratégias da justiça política ${ }^{4}$, HÖFFE (2005) entende que com o estado de direito, é o poder jurídico quem detém o poder coercitivo, podendo ele efetivamente fazer justiça. O Estado, por conseguinte, está obrigado à Justiça; e o Direito justo é a forma legítima da convivência humana.

Diante do surgimento de tensões entre os poderes estatais, cobra-se do Poder Judiciário, não apenas exercer o controle da legalidade, mas também da própria constitucionalidade das normas editadas pelos parlamentares, além de muitas vezes gerar novas normas jurídicas pela jurisdição, sempre objetivando concretizar os objetivos fundamentais da sociedade ou nas palavras de Freitas (2014, p. 19), "as prioridades constitucionais vinculantes".

Doutrinando sobre os critérios de controle de constitucionalidade adotados pelo Constituinte pátrio, assevera Silva (2003, p. 49/50) que no Brasil vigem dois controles: o difuso (ou jurisdição constitucional difusa) e o concentrado (ou jurisdição constitucional concentrada): "verifica-se o primeiro quando se reconhece o seu exercício a todos os componentes do Poder Judiciário, e o segundo, se só for deferido ao tribunal de cúpula do Poder Judiciário ou a uma corte especial".

Também nesse diapasão afirma Moro (2004, p. 313) que nosso sistema jurídico traz um paradoxo, pois "em uma democracia, cabe aos representantes eleitos pelo povo a primazia na formulação das políticas públicas".

Não obstante esta máxima, a própria Constituição Federal outorga ao Poder Judiciário o exercício da jurisdição constitucional que decorre da atribuição dada a autoridades não eleitas " $d o$ poder de controle sobre as políticas públicas formuladas por autoridades eleitas" (MORO, 2004,

\footnotetext{
${ }^{3}$ Segundo Höffe (2005, p. 45-68), os poderes do Estado não existem por própria perfeição do poder, mas graças à renúncia do direito daqueles que compõem a própria sociedade. Os poderes estatais são legítimos porque se concluiu que as renúncias são vantajosas para o todo e para cada um, e porque se considera que é melhor a existência de um poder coletivo responsável pelo respeito às liberdades fundamentais.

${ }^{4}$ Para a teoria de Höffe (2005, p. 124-145), as estratégias de justiça política são os caminhos, os veículos, as formas que devem ser respeitadas para que haja comprometimento dos poderes públicos com a justiça. Possuem uma dupla face: o lado voluntário e o cognitivo. Höffe afirma que na discussão com o positivismo jurídico, distingue-se uma justiça definidora do direito de uma justiça normativa. Exemplo da primeira se tem com a proteção à vida. Responsabilidades jurídicas como a proteção à vida possuem o caráter de liberdades fundamentais ou direitos humanos. Garantir um mínimo deles para aqueles que se subordinam à coerção é um critério de definição; já garantir mais que um mínimo é um critério normativo do direito positivado.
}

Revista de Direito Brasileira | Florianópolis, SC | v. 23 | n. 9 | p.5-27 |Mai./Ago. 2019 
p. 314), sendo que essa contradição poderia se revelar uma situação antidemocrática. Ele, porém, afasta tal raciocínio, aduzindo que a jurisdição constitucional objetiva resgatar o caráter deliberativo da democracia, em contraposição a um processo de trocas compensatórias entre interesses privados alheios ao ideal republicano. Nesse sentido afirma que:

O juiz constitucional não pode perder de vista sua função, que a Constituição lhe atribuiu, de guarda da democracia e dos direitos fundamentais. O eficaz cumprimento de tal tarefa demanda a adoção de salutar ativismo judicial, quando for possível defendê-lo com base em argumentos que apelem para a própria democracia. Se a atuação judicial contribuir para o aprofundamento da democracia, não há como acusá-la de antidemocrática. (MORO, 2004, p. 315)

Ao Judiciário brasileiro cabe, portanto, a tarefa fundamental, principalmente em um Estado de direito em construção, de controlar a constitucionalidade das normas e dos atos normativos no caso concreto, protegendo os direitos fundamentais do homem, entre eles os direitos sociais, culturais e econômicos, realizando uma total integração entre os atos editados pelos Poderes do Estado (RIBEIRO, MIRANDA, 2016, p. 139-157; SCHEIFER; MANDALOZZO, CAMPAGNOLI, 2016, p. 158-172).

\section{INTELIGÊNCIA ARTIFICIAL E METODOLOGIA FUZZY NA ATUAÇÃO JUDICIAL}

Um dos pontos de maior relevância em matéria de proteção constitucional está na efetivação dos direitos sociais (direitos de segunda geração) ${ }^{5}$. Esses direitos sociais têm por objetivo primeiro criar um social welfare ${ }^{6}$ que garanta a todos os cidadãos uma vida digna, financiada pelas receitas fiscais arrecadadas junto a toda a coletividade, como forma de redistribuição da riqueza entre todos. Exatamente por isso que, apesar da previsão de obrigações a serem cumpridas por toda a sociedade e a possibilidade de outras instituições participarem do atendimento das políticas públicas (como o Terceiro Setor), ainda prevalece o paradigma que garante que a concretização dos direitos sociais seja tarefa primordial da Administração Pública.

Ponto central está na discussão acadêmica sobre em que medida esses direitos se traduzem em direitos subjetivos às prestações positivas do Estado, inclusive passíveis de serem garantidos por meio do acesso ao Poder Judiciário. Tais discussões partem de três polos de debates: a necessidade de implementação desses direitos aos seus destinatários, a vontade política de concretizá-los e a existência de dinheiro nos cofres públicos (ou, em várias medidas, entre o mínimo existencial, compromisso político e a reserva do financiamento possível). ${ }^{7}$

\footnotetext{
${ }^{5}$ Para Brega Filho (2002, p. 22-23) a classificação histórica dos direitos fundamentais, feita do ponto de vista das gerações, aponta que "foram definidos e assegurados os direitos sociais, econômicos e culturais buscando garantir condições sociais razoáveis a todos os homens para o exercício dos direitos individuais." (...) Esses direitos foram chamados de direitos fundamentais de segunda geração e "caracterizam-se, ainda hoje, por outorgarem ao indivíduo direitos a prestações sociais estatais, como assistência social, saúde, educação, trabalho, etc., revelando uma transição das liberdades formais abstratas para as liberdades materiais concretas”.

${ }^{6}$ Social welfare é utilizado, aqui, como o bem-estar da sociedade.

${ }^{7}$ Habermas faz uma distinção interessante "entre questões morais da justiça e questões éticas de auto-entendimento". Ele aborda o problema "sob o ponto de vista que se pergunta sobre qual a regulamentação mais adequada ao interesse equânime de todos os atingidos (sobre 'o que é bom em igual medida para todos')" e de outro lado, ele aborda "as alternativas de ação a partir da perspectiva de indivíduos ou de coletividades que querem se assegurar de sua identidade, bem como saber que vida devem levar, à luz do que são e do que gostariam de ser (ou seja, 'o que é bom para mim, ou para nós, no todo e a longo prazo')." (Habermas, 2008,p. 313). Pouco mais á frente, afirma o filósofo alemão que "certamente, uma cultura política 'transigente' nasce do contexto de uma respectiva história nacional; mas o que ela faz valer para uma cultura política 'liberal', que gera e funda em sociedades pluralistas uma consciência civil partilhada, para além de todas as diferenças, é a remissão aos princípios da Constituição, universalistas e prenunciadores da igualdade de direitos" (idem, p. 317)
}

Revista de Direito Brasileira | Florianópolis, SC | v. 23 | n. 9 | p. 5-27 |Mai./Ago. 2019 
Referido debate aponta que a efetivação dos direitos fundamentais em sua dimensão prestacional (positiva) tem custos públicos, repassados para toda a coletividade, dando significativa ênfase às escolhas políticas dos membros dos poderes do Estado $^{8}$.

Essa polarização entre necessidade social e disponibilidade orçamentária levou a uma escolha doutrinária no sentido de que as normas que consagram os direitos sociais são meras normas programáticas dependentes da criação (pelo legislativo e executivo) de políticas públicas específicas, mediante a adoção de critérios distributivos dos recursos públicos em face da utilização de valores variáveis em função das necessidades coletivas ou individuais dos cidadãos. Somente a partir dessa determinação, haveria a possibilidade de se exigir uma concretização pelo Estado, e mais ainda, exigir sua efetividade perante o Poder Judiciário, sob pena de violação do princípio da separação de poderes e do princípio da reserva do financeiramente possível.

De tal entendimento discorda Canotilho (1998, p. 39), pois, para ele, há uma frequente confusão entre direitos sociais e políticas públicas de direitos sociais. Para o autor lusitano, os direitos sociais são vistos como normas abertas e indeterminadas (fuzzy), sem limitação interpretativa dada pelo estabelecimento de efetivas políticas públicas pela lei material. O autor critica essa ampla implementação feita pelo Poder Judiciário, a qual deixa claro que os aplicadores da lei não sabem bem o que fazem.

Nas palavras de Canotilho (1998, p. 37), alguns paradoxos e fragilidades relativos a métodos e escolhas metodológicas (e pré-compreensões) adotadas por doutrinadores (tal como aquela adotada por Rawls) no campo das teorias da justiça "dificultan hoy la tarea de todos aquellos que procuran la articulación entre normatividad y eficacia a través de un discurso jurídico-constitucional moralmente reflexivo". Para ele, os direitos de segunda geração ainda não encontraram uma definição concreta sobre seus conteúdos práticos. Essa dificuldade metodológica na fixação do conteúdo concreto dos direitos sociais encontra similitude com a chamada "metodologia fuzzy", pois esses direitos se encontrariam em uma zona cinzenta, nebulosa.

O autor português (CANOTILHO, 1998, p. 37-38) afirma que os direitos sociais "aparecen envueltos em cuadros pictóricos donde el recorte jurídico cede el lugar a normativas faltas de claridade. Y aqui és donde surge el 'camaleón normativo", em face da indeterminação de um sistema jurídico aberto e passível de controle judicial. Explica Canotilho (1998, p. 38) que a expressão camaleão normativo não é uma expressão criada por ele, mas tem todo um sentido que ajuda na compressão do próprio direito. Afirma ele que a expressão "camaleão normativo"

Fue utilizada por el conocido constitucionalista alemán J. Ssensee hace más de quinze años. Com ella pretendia señalar la inestabilidad e imprecisión normativa de um sistema jurídico aberto - como el de los derechos sociales - ya a contenidos normativos inmanentes al sistema (system-inmanente), ya a contenidos normativos transcendentes al mismo sistema (system-transzedente). Esta indeterminación normativa explicaria, em gran medida, la confusion entre contenido de um derecho juridicamente definido y determinado y sugestión de contenido, sujeita a modelacione político-jurídicas cambiantes. Em otras palavras: el 'transformismo normativo' dará lugar al trânsito de um discurso jurídico riguroso, centrado em categorias como 'los derechos subjetivos' y 'los deberes jurídicos', hacia um discurso político-constitucional basado em programas concretizadores de 'princípios rectores' y de directivas políticas.

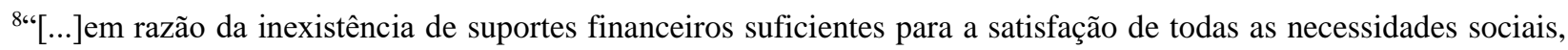
enfatiza-se que a formulação das políticas sociais e econômicas voltadas à implementação dos direitos sociais implicaria, invariavelmente, escolhas alocativas. Essas escolhas seguiriam critérios de justiça distributiva (o quanto disponibilizar e a quem atender), configurando-se como típicas opções políticas, as quais pressupõem "escolhas trágicas" pautadas por critérios de macro-justiça. É dizer, a escolha da destinação de recursos para uma política e não para outra leva em consideração fatores como o número de cidadãos atingidos pela política eleita, a efetividade e eficácia do serviço a ser prestado, a maximização dos resultados, etc." (STF, Suspensão de Liminar n ${ }^{\circ}$ 47/PE; p. 3).

Revista de Direito Brasileira | Florianópolis, SC | v. 23 | n. 9 | p.5-27 |Mai./Ago. 2019
} 
No plano da ciência computacional, a lógica fuzzy já alcançou plena aplicabilidade, evoluindo para aquilo que chamam de "metodologia fuzzy". E com a expansão da informática e sua aplicação agora diuturna na prestação da tutela jurisdicional, teve sua concepção exportada para o campo do direito.

Dill (2005, p. 47-48) falando sobre a lógica fuzzy (termo sinônimo para incerto, impreciso, difuso ou nebuloso), expõe que ela se revela uma ferramenta útil para a área de análise de situações incertas e ambíguas, inicialmente no campo computacional, mas passível de utilização no campo de ciências humanas, como forma de mensurar riscos e incertezas, inclusive na área de análise de crédito, de desenvolvimento de modelos contábeis e financeiros, diagnose financeira com base na Teoria dos Conjuntos Nebulosos; neurofuzzy para identificar fraudes financeiras ou até consumerista aplicada à análise das decisões do consumidor.

Em 1965, o professor Lotfi Zadeh publicou o primeiro trabalho de pesquisa sobre a teoria da Lógica Fuzzy, também conhecida como lógica nebulosa, que trata dos conjuntos não totalmente verdadeiros nem tampouco totalmente falsos. De maneira geral, a Lógica Fuzzy deve ser vista como uma teoria matemática formal para a representação de incertezas (...)" (DILL, 2005, p. 47-48).

Aduz o referido autor (DILL, 2005, p. 49), ainda, que

Uma das principais características da lógica nebulosa é a de representar uma forma inovadora de manuseio de informações imprecisas. A lógica nebulosa pode prover um método de traduzir expressões verbais, vagas, imprecisas e qualitativas, comuns na comunicação humana em valores numéricos.

Para Rignel et al (2011, p. 17-27), o conceito fuzzy parte de uma situação que não admite respostas simples como "sim" ou "não" "pois mesmo conhecendo as informações necessárias sobre a situação, dizer algo entre "sim" e "não", como "talvez" ou "quase", torna-se mais apropriado". E conclui que

Essa lógica permite que variáveis não admitam valores precisos necessariamente, como 0 ou 1, possibilitando que elas tenham graus de pertinência entre os elementos, em relação ao seu conjunto. Possibilita ainda a construção de várias regras, que facilitam a modelagem dos problemas, tornando-os assim, menos complexos. Tal lógica atrai pesquisadores da área e diversos profissionais de tecnologia da informação, pelo fato dela tornar geralmente mais simples as soluções dos diversos problemas complexos existentes atualmente (RIGNEL, 2011, p. 26-27).

Malaman (2013, p. 37) afirma que a lógica formal (booleana ou binária) tenta explicar como funciona o pensamento humano, detectando que uma certa afirmação ou é verdadeira ou falsa, nada existindo entre estes polos. Segundo a autora, diferentemente da lógica booleana, "na lógica fuzzy não existe somente respostas extremas. Ela permite atribuir um grau de aproximação da solução exata e assim inferir algo que seja necessário" (2013, p. 14), apontando que um conjunto fuzzy "é caracterizado por uma função de pertinência que atribui a cada elemento um grau" (2013, p. 37). Explica a autora, em sua dissertação de mestrado, que

Os conjuntos Fuzzy podem ser associados às variáveis linguísticas (sic) que possibilitam descrever as informações de maneira qualitativa, ou seja, seus valores estão relacionados a palavras ou frases, não a números (BENINI; MENEGUETTE JUNIOR, 2009). A variável sempre está ligada a um conjunto que determina quais os valores ela pode assumir. Por exemplo, para a variável temperatura da água, seus valores podem ser "fria", "morna" e "quente". 
A inferência fuzzy é fundamentada sobre a implicação e a composição de regras que, por meio de proposições condicionais do tipo "se" e "então" e com base em variáveis linguísticas, chega-se a um resultado que permite tomar decisão.

A capacidade em descrever ou classificar detalhes de forma gradual permitindo uma aproximação muito maior da realidade faz com que a lógica fuzzy possua as mais diversas aplicações que vão desde soluções em desenvolvimento industrial, ciências ambientais até na área de negócios e finanças.

Dill (2005, p. 48) aponta que o método fuzzy é composto de três estágios ${ }^{9}$ :

[...] um estágio de entrada (crisp), um estágio de processamento e um estágio de saída. O estágio de entrada mapeia dados de entrada de maneira apropriada às funções consecutivas e valores verdadeiros. O estágio de processamento é aquele em que se procura alcançar a solução para os problemas, podendo ser dividido em três passos básicos: fuzzificação, regras de avaliação e defuzzificação. Aqui é invocada cada regra adequada que gera um resultado para cada uma delas e, então, combinam-se os resultados dessas regras. Por último, tem-se um estágio de saída cujo resultado, já defuzzificado da operação, é colocado para dentro do sistema, executando um controle (saída crisp).

O estágio de processamento da aplicação da metodologia fuzzy compreende também três fases: a primeira fase é dedicada à construção das variáveis fuzzy de entrada (fuzzyficação); na segunda fase, a construção das regras de inferência pertinentes ao modelo; e na terceira fase, a defuzzyficação (DILL, 2005, p. 47-50), que seria por sua vez o processo de colocar nomes no universo de discurso de cada entrada crisp $^{10}$.

Não por outra razão, afirma Dill (2005, p. 48-50) que:

O passo final no processamento da lógica fuzzy é a defuzzificação. Aqui o valor de uma variável de saída é derivado isolando um valor crisp dentro do universo de discurso dos conjuntos fuzzy de saída. Ou seja, os valores do processamento da lógica fuzzy terminam com o seu retorno em forma de saída não fuzzy, ou seja, uma saída crisp ${ }^{11}$.

Concluindo seu trabalho acerca de rentabilidade das empresas com a aplicação de processos de fuzzyficação, Dill (2005, p. 102) conclui que "a lógica nebulosa permitiu tratar, de forma numérica, predicados tais como "péssimo", "deficiente", "fraco", "razoável", "satisfatório", "bom" e "ótimo", e que um modelo lógico linear não possibilitaria "a mesma flexibilidade no tratamento das variáveis qualitativas."

Estudando a especificidade da lógica fuzzy, Serbena (2013, p. 18) afirma que ela contrasta com a lógica clássica, pois ela pode sofrer influência de outros domínios, inclusive de crenças e posições filosóficas. Para o autor

[...] as proposições podem assumir não somente um valor falso ou verdadeiro, como na lógica clássica, mas um valor com um certo grau de falsidade ou de verdade. Este valor ou grau de verdade ou falsidade pode ser interpretado de diversas maneiras: o grau de verdade pode ter uma quantidade de crença, um grau de probabilidade, ou um grau de certeza. Há diversas interpretações para a lógica fuzzy, de modo que o significado das proposições fuzzy depende da posição filosófica ou teórica adotada ao interpretar-se o sistema fuzzy.

\footnotetext{
${ }^{9}$ Serbena(2013, p. 20) apresenta um diagrama que possibilita a visualização de todo o método fuzzy.

${ }^{10} \mathrm{O}$ universo de discurso pode ser descrito como a faixa de valores associados a uma variável fuzzy, onde são definidos vários conjuntos fuzzy dentro de um universo de discurso, cada qual com o seu próprio domínio que sobrepõe com os domínios dos seus conjuntos fuzzy vizinhos. Ou seja, o universo de discurso se refere ao domínio que se dá a um determinado conjunto. No direito brasileiro, temos na definição do grau de deficiência física ou mental a aplicação dessa fuzzificação, como se vê da Portaria interministerial no $1 / 14$, o que será analisada a seguir.

${ }^{11}$ Fuzzy é entendido como nebuloso, indeterminado, vago; e crisp é entendido como determinado, certo.
} 
Para o leitor pode ficar a pergunta: mas o que a lógica nebulosa pode interessar à atuação judicial? Sem querer esgotar a resposta, é possível concluir que hoje essa lógica fuzzy tem sido aplicada na construção de mapeamentos de decisões, de resultados, de necessidades, com outras possibilidades de aplicação no campo do direito e mais propriamente no campo da atuação judicial, pois "uma das grandes utilidades da lógica fuzzy para o direito é o fato de constituir-se em uma ferramenta capaz de capturar informações imprecisas, descritas em linguagem natural, e convertê-las para um formato numérico" (SERBENA, 2013, p. 18). Aduz o autor que

Muitas expressões da linguagem natural são utilizadas de modo vago, sem uma precisão quantitativa, e a lógica fuzzy é capaz de tratar esta imprecisão e convertê-la em um valor preciso. São exemplos de termos vagos da linguagem natural os adjetivos muito, pouco, longe, perto, um pouco cheio, um pouco vazio, etc. ${ }^{12}$

Para Serbena (2013, p. 14), a lógica fuzzy pode ser aplicada na chamada informática decisória (onde "os sistemas informatizados podem simular, imitar a inteligência humana, e através deste processo, decidir e alcançar uma resposta para certas questões"). Para o autor, a informática decisória se revela, hoje, uma evolução também no campo do direito, por permitir que "os sistemas informatizados também tomem decisões de forma dependente de um agente humano ou mesmo de forma autônoma, automatizando o processamento da informatização ou mesmo contribuindo para tal". Ressalta, desde logo, que

[...] o objetivo não é eliminar a decisão humana dos processos decisórios e dos processos judiciais. Qual será a decisão humana sobre a decisão computacional, o que será feito com ela, qual será seu valor pragmático, é uma questão paralela, mas que com ela não se confunde. [...] Em outras palavras, uma ferramenta computacional baseada em inteligência artificial pode, no mínimo, auxiliar a decisão humana, e este uso mínimo já justificaria a sua adoção. (SERBENA, 2013, p. 14)

Serbena (2013, p. 14) propõe que as ferramentas de informática decisória sejam construídas com a utilização do método ou lógica fuzzy e pela adoção de redes neurais, não de forma exclusiva, mas sim através de uma abordagem complementar.

A primeira (lógica fuzzy), já foi amplamente explicitada acima, enquanto que em relação às RN, afirma o autor (SERBENA, 2013, p. 21) que "são uma técnica de programação que procura modelar e imitar alguns princípios do cérebro humano", especialmente a inteligência demonstrada na capacidade de aprender. Acrescenta que "uma RN passa por um período de aprendizado, onde os dados são inseridos no sistema" e depois, há uma comparação entre todos os dados "e permite, por exemplo, que nos próximos cem casos, repetir os mesmos padrões adotados quando os dados foram inseridos".

A RN tenta trabalhar em uma situação similar ao funcionamento do neurônio biológico "através da construção de uma rede de neurônios artificiais" (SERBENA, 2013. P. 23-24). Segundo o autor, uma rede neural básica é composta, em síntese, de três momentos específicos, “a) um conjunto de entradas; b) um conjunto de pesos, que atuam de maneira dinâmica sobre os

\footnotetext{
${ }^{12}$ Serbena, continuando sua explicação no mesmo parágrafo mencionado acima, entende que a lógica fuzzy poderia ter uma boa aplicação na dosimetria da pena, em matéria penal, para o estabelecimento da pena base, ou seja, na análise da culpabilidade do agente, antecedentes, conduta social, personalidade, motivos, circunstâncias, consequências do ato criminoso, etc. Para o autor, o juiz acaba agindo de forma subjetiva e intuitiva na fixação dessas condicionantes, sendo que a lógica fuzzy poderia trazer maior racionalidade neste ponto.
}

Revista de Direito Brasileira | Florianópolis, SC | v. 23 | n. 9 | p. 5-27 |Mai./Ago. 2019 
neurônios da rede; e c) um conjunto de neurônios de saída, que fornecem o sinal de saída da rede neural".

A capacidade de aprender, das redes neurais ( $\mathrm{RN}^{\prime}$ 's), revela-se "na capacidade de receber treinamento e de certo modo 'aprender' a dar uma resposta para uma determinada classe de problemas" (SERBENA, 2013, p. 24). Esse processo de treinamento da rede está exatamente na possibilidade de realização de um "processo de ajuste dos pesos". Este ajuste dos pesos pode ser classificado de acordo com quem o promove: em aprendizado supervisionado ou não supervisionado (o primeiro feito por um agente externo, enquanto que o segundo se dá mediante um exemplo de objetos ou padrões semelhantes para que responda de modo semelhante).

Para Serbena (2013, p. 25), o ajuste de pesos pode, ainda, ser classificado de acordo com a função da finalidade do aprendizado, revelando-se auto-associador ou hereto-associador (o primeiro se dá mediante "uma coleção de exemplos apresentada à rede para que ela os memorize. Quando um dos elementos da coleção de exemplos for apresentado de modo errôneo, a rede deve ser capaz de mostrar o exemplo original". Já o segundo, é uma variação do primeiro, sendo que "a diferença consiste na memorização de um conjunto de pares. Neste aprendizado, a rede funciona como um reconhecedor de padrões, sendo capaz de reproduzir o segundo elemento do par mesmo que o primeiro esteja pouco modificado"). ${ }^{13}$

Carneiro (2013, p. 17-27), faz uma aproximação entre lógica, direito e justiça, apontando que no campo do direito obrigacional (com ênfase à questão do dano moral) é possível aplicar a lógica matemática na quantificação do descumprimento obrigacional ou mesmo do grau do dano sofrido ou sua quantificação, inclusive com o emprego da lógica fuzzy para solucionar lacunas ou para a verificação de fatores determinantes, contradições, antinomias, incertezas e vaguidades de situações, podendo levar a uma maior coerência na aplicação do direito e emantar uma maior isonomia e segurança jurídica entre os contratantes.

No campo dos direitos sociais, já temos a aplicação do método fuzzy ou lógica nebulosa no direito brasileiro, mais especificamente para a fixação do grau de deficiência física para a concessão das aposentadorias por tempo de contribuição ou por idade da pessoa com deficiência. $\mathrm{Na}$ forma da Lei Complementar $\mathrm{n}^{\circ}$ 142/13, a definição da pessoa com deficiência está em seu artigo $2^{\circ}$, sendo assim considerada a pessoa que tem impedimentos de longo prazo de natureza física, mental, intelectual ou sensorial, os quais, "em interação com diversas barreiras, podem obstruir sua participação plena e efetiva na sociedade em igualdade de condições com as demais pessoas".

O mesmo estatuto legislativo complementar define os graus da deficiência, fixando-os em grave, moderada e leve, podendo a pessoa que comprovar estar em um dos três graus se beneficiar com a redução da idade na concessão da aposentadoria por idade (as pessoas com deficiência se aposentam com a idade de 60 anos, se homem, e 55 anos, se mulher, desde que preenchidos os outros requisitos específicos), com uma redução de 5 anos se comparados aos demais segurados do regime geral de previdência social. O grau da deficiência também leva a uma redução de tempo de contribuição de dez, seis ou dois anos, respectivamente, para a pessoa com deficiência, conforme seu grau de deficiência seja grave, moderado ou leve.

A Lei Complementar $n^{\circ} 142 / 13$ tem inúmeros termos, expressões, institutos, de conteúdo indeterminado. E o maior deles, a definição do que é pessoa com deficiência ou o grau dessa mesma deficiência, não tem conteúdo concreto, ficando sua análise para uma perícia

\footnotetext{
${ }^{13}$ Serbena retrata um estudo de seu orientando, Christian Grimm, que programou uma rede neural, baseando-se nas regras do Código Penal Brasileiro, para o cálculo da pena base em ações criminais (2013, p. 26-29), e conclui que “a resposta da RN a partir do treinamento a ela proposto demonstra a sua efetiva utilidade como ferramenta analítica poderosa, capaz de mensurar e radiografar a estrutura de uma decisão humana". Conclui, também, que a RN, como treinada pelo seu aluno, pode ser utilizada também na área administrativa, tal como na fixação de multas e outras sanções discricionárias, além da criação de um conciliador virtual (2013, p. 29).
} 
biopsicossocial a ser feita pelo próprio Estado. E para a realização dessa análise, o regulamento da referida lei (Decreto 3.048/99, em seu artigo 70-A a 70-I), exige que essa perícia se dê em conformidade com ato conjunto do Ministro de Estado Chefe da Secretaria dos Direitos Humanos da Presidência da República, dos Ministros de Estado da Previdência Social, da Fazenda, do Planejamento, Orçamento e Gestão e do Advogado Geral da União.

$\mathrm{O}$ ato conjunto se concretizou na edição da Portaria Interministerial $\mathrm{n}^{\mathrm{o}} 1$, de 27 de janeiro de 2014, que aprovou o instrumento destinado à avaliação da deficiência e do seu grau. E nessa portaria vem criado o Índice de Funcionalidade Brasileiro aplicado para fins de classificação e concessão da aposentadoria da pessoa com deficiência - IF-BrA. Este índice, para seu cálculo, utiliza-se de seleção de itens de atividades e formas de participação, de acordo com a Classificação Internacional de Funcionalidade (CIF) criada pela Organização Mundial da Saúde (OMS), com determinação de pontuação para cada um dos sete domínios ${ }^{14}$ - que podem ser entendidos como universo do discurso, como apontado por Dill (2005) nas páginas anteriores - e no grau de independência em cada um, equivalente a 25, 50, 75 ou 100 pontos. De acordo com a Medida de Independência Funcional-MIF, o IF-BrA será apurado pela soma da pontuação alcançada pelo segurado posteriormente comparado com os graus definidos também em números de pontos, com a incidência da variação do Método Fuzzy. ${ }^{15}$

Assim, o método fuzzy acima descrito, está sendo utilizado na concessão da prestação social vinculada à previdência e assistência social, como forma de auxiliar na interpretação legal dos conceitos vagos estampados na lei e que criam uma grande indefinição na fixação do que se entende por pessoa com deficiência e os graus de deficiência possíveis de serem protegidos pela norma legal.

O método fuzzy aplicado na matéria ora tratada auxilia a Administração Pública e até mesmo o magistrado, nas considerações subjetivas do caso concreto, considerando que conteúdos subjetivos variam de um intérprete ou aplicador para outro. Já o acerto da pontuação no caso concreto dependerá da análise subjetiva do magistrado, de acordo com seu livre convencimento na análise da prova produzida.

A inteligência artificial, decorrente do uso da internet vem se mostrando uma interessante ferramenta para controles de dados da administração pública, auxiliando na busca da concreta transparência administrativa. Podemos mencionar três formas de controle social pela utilização da IA, como a Operação Serenata de Amor ${ }^{16}$, vinculada ao Observatório Social.

A operação Serenata de Amor é um projeto aberto que usa ciência de dados - similares às tecnologias utilizadas por grandes corporações de redes sociais, como Google, Facebook e Netflix, tendo por objetivo analisar e fiscalizar gastos públicos de deputados federais e senadores, e compartilhar as informações de forma acessível a qualquer interessado, inclusive apontando cobranças ou recebimentos indevidos através do twitter.

Na referida operação, foram criados o robô Rosie e o site Jarbas. A função da Rosie é a de analisar os gastos reembolsados ou requeridos pelo parlamentar no gozo da Cota para Exercício da Atividade Parlamentar (CEAP), identificando suspeitas e incentivando a população a questionar tais valores. Já o site Jarbas possibilita que a sociedade entenda as informações

\footnotetext{
${ }^{14}$ Os sete domínios são: sensorial; comunicação; mobilidade; cuidados pessoais; vida doméstica; socialização e vida comunitária; e educação, trabalho e vida econômica.

${ }^{15}$ Para uma análise mais ampla acerca da referida Lei Complementar $\mathrm{n}^{\circ}$ 142/13 e os benefícios previdenciários destinados à pessoa com deficiência, apontamos a tese de mestrado: LINO, Leandro Jorge de Oliveira. A visão monocular e a aposentadoria especial da pessoa com deficiência. UNESP/Franca, 2017.

${ }^{16}$ Sobre a operação Serenata de Amor, maiores informações em https://serenata.ai/, acesso em 01/06/2018. Outros projetos similares de controle social de gastos públicos podem aqui ser mencionados, como o Observatório Social do Brasil e o OPS - Operação Política Supervisionada. As coordenadas podem ser obtidas no sitehttp://www.politicos.org.br/blog/3-ferramentas-para-fiscalizar-as-contas-publicas-voce-pode-participar. Acesso em $01 / 06 / 2018$
}

Revista de Direito Brasileira | Florianópolis, SC | v. 23 | n. 9 | p. 5-27 |Mai./Ago. 2019 
geradas pela Rosie e que os cidadãos naveguem pelos gastos (notas fiscais, locais do consumo, cidade, viagem, voos, etc) como forma de descobrir mais sobre cada suspeita. ${ }^{17}$

Ainda como forma de atuação na área do direito, temos a utilização do método Fuzzy-set para análise de decisões judiciais, como forma de "promover a comparação de resultados semelhantes de casos distintos para deles extrair outras variáveis independentes hábeis a apontar outros cenários" (SOMBRA, 2017, p.7). Auxilia o operador do direito a entender situações similares para, no futuro, aplicar os resultados a outros casos concretos.

A e-justiça já está se transformando em realidade com a informatização do processo e criação de formas lógicas e inteligentes - artificiais - de lidar com o direito. Existem diversas frentes de pesquisa sobre a criação de ferramentas e programas informatizados para auxílio à prestação jurisdicional, alguns apontando até a possibilidade de criação do juiz digital (ou juiz virtual), cuja operacionalização, se estabelecida, poderá se utilizar da metodologia fuzzy associada à inteligência artificial.

Podemos mencionar outros exemplos de como a inteligência artificial pode ser utilizada no processamento e controle de processos judiciais.

Uma das formas se dá exatamente no estabelecimento de processos judiciais virtuais (tais como o PJ-e, o e-proc, o SISJEF - sistema informatizado dos Juizados Especiais Federais da Justiça Federal da Terceira Região-, entre outros) ${ }^{18}$, onde o processamento se realiza pela utilização de sistemas informatizados que controlam as fases processuais, os prazos judiciais, os dados estatísticos, e onde são produzidos os atos e decisões judiciais (apenas com a utilização do sistema como meio mecânico de elaboração).

Outro exemplo é a utilização da inteligência artificial para a sistematização da jurisprudência do Supremo Tribunal Federal, que se encontra em fase de efetiva implantação, tendo por objetivo agilizar a tramitação dos processos submetidos ao julgamento naquela Corte Constitucional. A ferramenta de inteligência artificial foi batizada de Victor $^{19}$ e em um primeiro momento, ele irá "ler" todos os recursos extraordinários que tenham sido admitidos e "identificar quais estão vinculados a determinados temas de repercussão geral”. Essa ação esperada da ferramenta representa apenas uma parte da fase inicial do processamento dos recursos no Tribunal, "mas envolve um alto nível de complexidade em aprendizado de máquina", em fase de construção de suas redes neurais "para aprender a partir de milhares de decisões já proferidas no STF a respeito da aplicação de diversos temas de repercussão geral", esperando-se que Victor seja capaz "de alcançar níveis altos de acurácia - que é a medida de efetividade da máquina -, para que possa auxiliar os servidores em suas análises"20.

\footnotetext{
${ }^{17}$ Em janeiro de 2017, foi realizada "uma hackaton de denúncias - um mutirão para dar vazão aos mais de 3.000 reembolsos suspeitos apontados pela Rosie, nossa inteligência artificial que analisa gastos da Cota para Exercício da Atividade Parlamentar (CEAP)". Foram auditados 849 casos, com 629 denúncias que significam um valor suspeito de R\$ 378.844,05, e que foram questionados junto à Câmara de Deputados (216 deputados foram denunciados; o deputado vencedor teve 43 denúncias diferentes; os casos denunciados mais comuns foram de refeições superfaturadas ou de deputado pagando refeições para outras pessoas). Exemplo de uma denúncia: "SerenataDeAmor Denunciado à @CamaraDeputados deputado tomando R\$ 170 de açaí (de uma vez só). — @pedrovilanova". Dados extraídos do endereço: https://medium.com/data-science-brigade/o-resultado-domutir\%C3\%A3o-de-den\%C3\%BAncias-\%C3\%A0-c\%C3\%A2mara-321ef0825888.

18 Os Juizados Especiais Federais foram os precursores dos processos judiciais 100\% virtuais (decorrente da aplicação do artigo 154 do CPC/73 cc Lei n n $^{\circ}$ 10.259/01), com aplicação das normas trazidas pela Lei do processo Eletrônico (Lei no 11.419/06).

${ }^{19}$ O nome do projeto, VICTOR, é uma "homenagem a Victor Nunes Leal, ministro do STF de 1960 a 1969 , autor da obra Coronelismo, Enxada e Voto e principal responsável pela sistematização da jurisprudência do STF em Súmula, o que facilitou a aplicação dos precedentes judiciais aos recursos", conforme extraído do site http://www.stf.jus.br/portal/cms/verNoticiaDetalhe.asp?idConteudo=380038, acesso em 31/05/2018.

20 Extraído do site: http://www.stf.jus.br/portal/cms/verNoticiaDetalhe.asp?idConteudo=380038, acesso em 31/05/2018. Dali se extrai, também, que "VICTOR não se limitará ao seu objetivo inicial. Como toda tecnologia, seu crescimento pode se tornar exponencial e já foram colocadas em discussão diversas ideias para a ampliação de suas Revista de Direito Brasileira | Florianópolis, SC | v. 23 | n. 9 | p.5-27 |Mai./Ago. 2019
} 
Ainda como exemplo da aplicação da inteligência artificial no campo do direito, temos a utilização da internet como forma de controle social da duração processual. O site Jota implantou uma ferramenta para monitorar o tempo de duração dos principais processos em tramitação no Supremo Tribunal Federal. Um robô, com o nome Rui, "soará um alerta automático via twitter quando estes processos fizerem aniversário ou completarem períodos específicos sem movimentação" 21.

Como se vê, a aproximação entre o Poder Judiciário e o jurisdicionado, através de programas e ferramentas informatizadas, tornada possível pelo uso da internet e da tecnologia da informação cria o necessário espaço para o estabelecimento da e-justiça, essa última como forma de democratizar o acesso à justiça ${ }^{22}$, de tornar a prestação da tutela jurisdicional mais célere, eficiente e eficaz, e de disponibilizar meios de maior controle social da própria atuação jurisdicional. Essa nova forma de relacionamento tem fomentado o surgimento de um novo ramo do direito, que aqui, de forma apenas reflexiva, poder-se-ia denominar $e$-direito ${ }^{23}$.

Pereira (2017, p. 12), reconhece a importância de estabelecer programas informatizados para auxiliar o magistrado na execução de seu mister. Afirma o autor português que "teoricamente, à semelhança da lógica informática, a lógica da norma legal é automática ou mecânica", e que na hipótese de verificação dos fatos constitutivos da "hipótese da norma, a respetiva estatuição aplicar-se-lhes-á" e acrescenta que

Assim, se o sistema fosse programado em termos de processar todo o corpo de normas legais em vigor, então seria possível tirar partido das vantagens criadas por tal informatização da justiça.

Os programas informáticos seriam o "braço direito" dos programas normativos da lei, i.e. o cumprimento dos programas normativos teria no programa informático um aliado da maior valia. Desde logo, porque reduziria drasticamente o erro dos juízes e de outros agentes da justiça justificado pela sua condição humana: errare humanum est (PEREIRA, 2017, p.12).

O mesmo autor (PEREIRA, 2017, p. 23-24) aponta que também no trato da informatização da jurisprudência e da doutrina os sistemas informatizados auxiliariam muito na prestação dos serviços judiciais, com os "usos correntes da jurisprudência e/ou às opiniões da doutrina".

habilidades. O objetivo inicial é aumentar a velocidade de tramitação dos processos por meio da utilização da tecnologia para auxiliar o trabalho do Supremo Tribunal. A máquina não decide, não julga, isso é atividade humana. Está sendo treinado para atuar em camadas de organização dos processos para aumentar a eficiência e velocidade de avaliação judicial. Os pesquisadores e o Tribunal esperam que, em breve, todos os tribunais do Brasil poderão fazer uso do VICTOR para pré-processar os recursos extraordinários logo após sua interposição (esses recursos são interpostos contra acórdãos de tribunais), o que visa antecipar o juízo de admissibilidade quanto à vinculação a temas com repercussão geral, o primeiro obstáculo para que um recurso chegue ao STF. Com isso, poderá impactar na redução dessa fase em 2 ou mais anos."

${ }^{21} \mathrm{https} / / / \mathrm{www}$.jota.info/dados/rui/prazer-rui-barbot-24042018

${ }^{22}$ No caso, o acesso à justiça decorrente da utilização da inteligência artificial se dá em coerência com as três ondas de acesso à justiça estabelecidas pela teoria de Cappelletti e Garth (1998, p. 69-72), importando no estabelecimento de vários meios de ampliação nas formas do processo, do procedimento e modernização na estrutura dos tribunais.

${ }^{23}$ A denominação desse novo ramo de direito ainda se encontra em construção, mas já se encontram as terminologias de direito cibernético, direito virtual, direito da informática, direito digital, direito eletrônico, juscibernética, ciberdireito, direito da internet, entre outros. Na Itália, temos os ramos Diritto dell'informatica ed elementi d'informatica giuridica da Facoltà di Giurisprudenza de Gênova ministrada desde 1992 pelo professor PASQUALE COSTANZO e Diritto dell'Internet, ministrado pelo mesmo professor, a partir de 1998 (extraído do site: http://www.costituzionale.unige.it/CURRICULUMCOSTANZO.pdf, acesso em 04/06/2018). Na Argentina, Derecho de Internet, como se vê do site http://www.abogados.com.ar/programa-de-derecho-de-internet-y-tecnologiade-las-comunicaciones-ditc-udesa/19558, acesso em 04/06/2018. Na Espanha, também Direito de Internet, conforme informações do site: https://www.inesem.es/Curso-En-Derecho-De-Internet-Nuevas-Tecnologias-Y-PropiedadIntelectual, acesso em 03/06/2018.

Revista de Direito Brasileira | Florianópolis, SC | v. 23 | n. 9 | p. 5-27 |Mai./Ago. 2019 
Mesmo aqui, todavia, as possibilidades de programação informática permitiriam dar resposta à porosidade linguística da lei, indexando tais conceitos indeterminados e cláusulas gerais a bases de dados jurisprudenciais e doutrinais processadas em termos de encontrar uma posição dominante ou maioritária.

Para tal, seria necessário encontrar um critério para aferir a dominância ou natureza maioritária de uma posição. Tarefa esta bastante delicada, mas nem por isso impossível, exigindo um trabalho constante de consolidação de doutrina e de jurisprudência, que poderia ter em conta, nomeadamente, o grau académico dos defensores de uma posição doutrinal e o grau hierárquico dos tribunais (e de outros agentes de justiça) subscritores de uma corrente jurisprudencial.

Porém, o autor deixa claro que nem mesmo a lógica do método fuzzy consegue humanizar a análise da lei e do caso concreto. Isso porque nem sempre a lei ou a jurisprudência são formuladas em termos claros, certos e lineares, pois em grande parte das vezes "utiliza conceitos indeterminados ou então cláusulas gerais. Nestas situações a lógica do «se..., logo» já é de pouco préstimo. A determinação de tais conceitos e a concretização dessas cláusulas não opera ope legis, sendo antes tarefa do intérprete" (PEREIRA, 2017, p. 24).

Concordamos com a ressalva feita por Pereira (2017, p. 25) e também com sua conclusão, para quem não é possível afastar o papel auxiliar dos sistemas de inteligência artificial ${ }^{24}$ na prestação jurisdicional, vez que "a ciência do bem e do mal e a justiça que nela se apoie são problemas do ser humano e como tais devem manter-se. Mais do que uma ficção, a justiça ex machina é uma aberração". Aduz Pereira (2017, p. 26) que:

Criatividade e juízo são categorias diferentes. Não é por conseguir criar soluções que a máquina "ganha juízo". (...) O juízo, enquanto capacidade de distinguir o bem e o mal e de valorar a situação em conformidade, exige compromisso e responsabilização do autor. O juízo exige, por outras palavras, um juiz, alguém que se comprometa com a decisão e que por ela se responsabilize, tendo em conta o papel da judicatura enquanto "viva vox iuris".52 Sem questionar o princípio constitucional da não responsabilidade dos juízes pelas suas decisões (art. 216. ${ }^{\circ}, 2$ ), parece-nos que substituir o juiz pela máquina seria confiar a justiça à irresponsabilidade e à arbitrariedade de uma lógica eventualmente «fuzzy».

A análise acima acerca aplicação de uma lógica formal, da lógica fuzzy, de metodologias objetivas e da inteligência artificial na concretização do direito enfrenta os limites deontológicos do próprio direito (como ciência social, pressupõe a presença da ética, a moral e dos valores sociais) e da necessária racionalidade jurídica conformada pela hermenêutica, retórica e argumentação jurídicas.

A relação fatos, valores e normas continua vívida na ciência do direito, trazendo o desafio da temperança entre metodologias tecnológicas de aplicação do direito e a hermenêutica jurídica.

Serbena (2013, p. 30) analisando a aplicação da lógica computacional ao direito, menciona que há sempre uma preocupação com a substituição do homem pela máquina na tarefa de julgar, porém, do ponto de vista matemático e quantitativo, "as máquinas e sistemas computacionais são mais eficientes e objetivos na medição e previsão de padrões de coerência do que os seres humanos, sempre sujeitos às considerações subjetivas de diversas espécies". Conclui o autor que

[..] se a decisão judicial que desejamos do sistema jurídico deva ser uma decisão coerente e igualitária, que leve em consideração todos os jurisdicionados na mesma

\footnotetext{
${ }^{24}$ Possível mencionar, entre as pesquisas, a que está em andamento por Rosina Weber Lee, denominada "Pesquisa jurisprudencial inteligente".
}

Revista de Direito Brasileira | Florianópolis, SC | v. 23 | n. 9 | p.5-27 |Mai./Ago. 2019 
medida, as RN podem auxiliar o julgador humano de forma bastante consistente" (SERBENA, 2013, p. 30).

A racionalidade jurídica vem, cada vez mais, adotando formas de aplicação objetiva do direito buscando uma maior padronização dos julgados (vezes com uso da lógica formal, computacional, interpretativa e tecnológica), criando um espaço juscibernético onde a possibilidade do próprio ato de julgar seja, em determinadas hipóteses, entregue a um computador ou a um juiz virtual. A máquina poderá criar e expedir, em breve, processamentos padrões, atos ordinatórios, controle de prazos, certificação de atos, análises de casos com requisitos-padrão para casos repetitivos, entre outras tantas situações possíveis, como forma de dar uma maior segurança jurídica.

Em regra, serão mantidos com os juízes (Judge human) os procedimentos intelectuais e interpretativos decorrentes do pensamento crítico e destinados a definir o sentido da lei e de aplicação da justiça concreta, porque dependem da história em constante mudança da sociedade (história cambiante).

A caminho dessa objetivação do direito, além do apontado acima, temos também outras medidas objetivas já encaminhadas pelo nosso sistema processual, como se vê dos chamados precedentes obrigatórios, forma interpretativa de criar métricas para a atuação jurisdicional na aplicação do direito ao caso concreto.

\section{PRECEDENTES OBRIGATÓRIOS E INTERPRETAÇÃO JUDICIAL}

Tratando da função social do processo civil, afirma Cambi (2009, p. 121) que a igualdade é a própria razão que a informa, pois o tratamento isonômico é "o significado políticofilosófico do movimento de acesso à justiça, uma vez que o processo não deve servir para beneficiar o litigante mais hábil, mais culto, mais forte, mas para dar razão à parte cujo direito seja superior".

Na chamada jurisdição constitucional, pode o juiz, quando do julgamento dos casos concretos que lhe são submetidos, deixar de aplicar a norma genérica e abstrata que repute inconstitucional, desde que o faça fundamentadamente, cabendo, de sua decisão, recursos que podem até mesmo chegar ao Supremo Tribunal Federal, órgão constitucionalmente encarregado de zelar pela correta aplicação da Constituição Federal.

Para Alves (2014), o Supremo Tribunal Federal tem legitimidade discursiva para tomar decisões para efetivação das normas constitucionais, porque ele tem como justificar o porquê de tomar determinada decisão, e depois sua decisão pode evoluir no transcorrer da história: por lei, por mudança do julgamento, alteração dos fatos, etc.

Nessa união das atribuições constitucionais, o interesse público deve nortear a atuação do Estado, em todas as suas esferas, devendo também o Poder Legislativo se pautar por ele, "sem ofensar aos direitos das minorias, sendo que a lei não passará no teste se o interesse político que ela explicitamente perseguir, não puder ser estreitamente relacionado com o conteúdo da lei" (MORO, 2003, p. 85), hipótese em que o juiz constitucional poderá afastar a regra jurídica por presumir que as reais motivações não cumpriram a ordem constitucional.

Souza Neto e Sarmento (2013, p. 119-161) afirmam que "este fenômeno de expansão da jurisdição constitucional e do seu papel político-social tem sido denominado de judicialização da política" e tem sido questionada em face da apontada "dificuldade contramajoritária" do Poder Judiciário, que é decorrente do fato de os "juízes, apesar de não serem eleitos, poderem invalidar as decisões adotadas pelo legislador escolhido pelo povo, invocando, muitas vezes, normas constitucionais de caráter aberto". Estas normas abertas (ou normas fuzzies ou nebulosas) levam à edição de leituras divergentes pelos cidadãos e pelo próprio Estado. 
Tratando do ativismo judicial, Alves (2014, p. 53-62) afirma que esse método vai além do direito, mostrando-se a maior forma de transgressão do texto normativo. Afirma o autor que, buscar a justiça por este meio, significa aplicar uma justiça individual do julgador, pois ele é que vai dizer o que é justo ou injusto. Isso faz com que qualquer concepção ou entendimento neste sentido sempre vai depender de um sujeito individualista, o que atenta contra a segurança jurídica. Entretanto, esta crítica não alcança a necessidade do magistrado de interpretar as leis e a Constituição Federal com base em princípios e normas postas.

Ecoando este entendimento, Alvin (2017, p. 2-3) aponta que a expressão ativismo judicial tem vários sentidos, indo desde a atividade interpretativa do juiz até uma atuação por meio da qual ele "exerce certa dose de criatividade, quando completa o sentido da norma". E isso porque são os juízes que decidem os casos concretos, fazendo-o "por meio de processos interpretativos cada vez mais complexos e que têm, de fato, o potencial de levar a decisões diferentes e desarmônicas entre si". E nesse passo, conclui a autora que apesar desta liberdade judicial de interpretar, "essa liberdade não é DO JUIZ: é do Judiciário. E mais do que isso, o juiz não deve

[...] criar direito do nada, da sua própria cabeça, seguindo suas convicções e crenças pessoais. Afinal, vivemos num Estado Democrático de Direito e o juiz deve decidir de acordo com a lei, interpretada pela jurisprudência, à luz da doutrina. O direito é um tripé: lei + doutrina + jurisprudência.

Tratando da possibilidade de aplicação da metodologia fuzzy na construção da racionalidade judicial, afirma Alvin (2017, p. 2-3) que cada vez mais se incluem "parâmetros de decisões ditos fuzzy ou 'nublados' nos textos do direito posto, como uma forma de tentar absorver a complexidade do mundo real'. Acrescenta Alvin (2017, p. 3) que tal se dá pelos conceitos vagos e pelas cláusulas gerais, pois

[...] é sintomática a necessidade que vem sendo sentida na comunidade jurídica, de que os princípios jurídicos integrem, de forma cada vez mais significativa, os raciocínios de direito.

Há tempos venho sustentando: estes parâmetros mais nublados ou, usando uma linguagem mais próxima ao dia a dia do operador do direito, conceitos indeterminados, cláusulas gerais e princípios jurídicos são poros que permitem à realidade penetrar no direito.

Não podemos perder de vista que na prestação jurisdicional como forma de pacificação social, a jurisdição constitucional (concentrada ou difusa) deverá efetivar os direitos fundamentais tendo por norte, sempre, a dignidade da pessoa humana que se revela como princípio fundamental do Estado Democrático de Direito brasileiro, conforme aduzido por Martins (2003, P. 104):

Enquanto valor inserto em princípio fundamental a dignidade da pessoa humana serve de parâmetro para a aplicação, interpretação e integração de todo o ordenamento jurídico, o que ressalta o seu caráter instrumental. Quando a Constituição elencou um longo catálogo de direitos fundamentais e definiu os objetivos fundamentais do Estado, buscou essencialmente concretizar a dignidade da pessoa humana".

Não é à toa que o próprio legislador, ao redigir as normas do Código de Processo Civil de 2015, não deixou outra possibilidade ao magistrado senão a de promover, em todas as suas decisões e nas interpretações de normas jurídicas insertas em nosso ordenamento jurídico - e não só o processual - a dignidade da pessoa humana, quando dispôs em seu artigo $8^{\circ}$ que na aplicação do ordenamento jurídico, "o juiz atenderá aos fins sociais e às exigências do bem comum, 
resguardando e promovendo a dignidade da pessoa humana e observando a proporcionalidade, a razoabilidade, a legalidade, a publicidade e a eficiência".

Como bem explanado por Tomé (2014, p. 232), este dispositivo revela a "inserção do materialismo da Constituição no ordenamento jurídico processual" e é o princípio-fonte de todo o direito processual nacional, pois é "o mais importante deles, que deve inspirar a interpretação e a aplicação de todo o conjunto de leis processuais, e não apenas as normas contidas no novo CPC'. Segundo o autor (TOMÉ, 2014, p. 232), do mencionado artigo se extrai

(...) importante mecanismo de inserção dos regramentos constitucionais no interior do Processo Civil. Basta ter presente que aludido texto foi explícito ao trazer para o âmbito do processo, não só o tema da dignidade da pessoa humana, mas também os métodos constitucionais de ponderação de valores e de aplicação de normas constitucionais, bem assim a proporcionalidade, a razoabilidade, a legalidade, a publicidade e a eficiência. Trata-se de cláusula geral capaz de oxigenar toda e qualquer interpretação das normas processuais, pelo viés constitucional e principalmente humanitário".

Diante de tais afirmações, temos que sucumbem as teorias atuais que defendem que a existência dos chamados precedentes obrigatórios deverão uniformizar todo e qualquer julgamento, como se criando regras lógicas a serem seguidas como se o juiz, além de "boca da lei", se apresente como um autômata (um computador), especialmente pelos magistrados de primeira instância, pois não lhes seria mais possível o exercício da plenitude da tutela jurisdicional, ainda que para reconhecer de forma central os direitos fundamentais do homem, de forma específica o da dignidade da pessoa humana.

Referida norma (artigo $8^{\circ}$ ) não trouxe uma mera regra processual a ser aplicada no processo civil. Trouxe, ínsita a ela, uma ressignificação da interpretação jurídica de toda e qualquer norma dentro da nossa ordem jurídica. Deve ser utilizada, inclusive, para a realização da ponderação entre um precedente editado para situações gerais e a aplicação do direito no caso concreto.

É claro que não podemos perder de vista a extrema importância da preservação do princípio da separação de poderes para a nossa Constituição Federal, mas também é importante não esquecer que a proteção dos direitos fundamentais é um dos pilares da nossa democracia e mais do que isso, do próprio Estado democrático de direito. Ponderar entre estas duas realidades, tendo a segurança jurídica como termômetro, consiste no grande embaraço atual do magistrado brasileiro, e que se revela na dificuldade da formação da nossa racionalidade jurídica. Isso porque, mesmo nas situações fáticas similares, poderemos encontrar um diferencial centrado no exercício, gozo ou reconhecimento de um direito fundamental que dará o tom da interpretação jurídica e a melhor solução para o caso concreto.

A previsibilidade do julgamento deve ser perseguido, também, por constituir um resultado natural da unidade do direito e por ser um fator de grande importância para a otimização da administração da justiça. Mas também não podemos esquecer que a aplicação da justiça é, também, imprescindível para o desenvolvimento da sociedade em um ambiente de respeito aos direitos fundamentais, não se admitindo que a atividade jurisdicional venha limitada por tabelas objetivas de solução do caso concreto (em clara aplicação da metodologia fuzzy acima descrita).

Para o positivismo constitucional que vivemos (ou positivismo jurídico contemporâneo), não é possível ao Estado viver na legalidade estreita e baseada na letra fria da norma jurídica ou do precedente obrigatório, ou, ainda, que o Poder Judiciário brasileiro se transforme em um instituto meramente chancelador dos atos do Legislativo e do Executivo, muitas vezes dominados pelas pressões mencionadas na parte inicial deste artigo.

Mas também não é demais observar que não se pode exigir que os juízes de instâncias inferiores atuem como chanceladores objetivos dos precedentes judiciais. Como aponta Pereira 
(2017), o direito não se confunde com algoritmos, números ou tabelas, pois naqueles não se apresentam os valores éticos do direito.

Nas palavras de Dworkin (2016, p. 10-11), "o texto de uma lei pode parecer suficientemente claro, porém é capaz de um resultado surpreendente quando interpretado literalmente".

Tal advertência deve incidir na análise dos chamados precedentes obrigatórios, que a doutrina pretende sejam adotados pelos juízes com força superior à própria força da lei. Na atual estrutura dos tribunais superiores do Poder Judiciário, não podemos afastar a incidência da influência político-partidária e de controle dos dois outros poderes sobre as decisões judiciais dos Tribunais encarregados de editar os precedentes chamados de obrigatórios (forma de ascensão aos cargos de desembargadores e ministros).

Exatamente por isso, no confronto entre um precedente e as normas constitucionais, devem prevalecer essas últimas, pois elas "podem ser corretamente interpretadas como instâncias que impõem limites morais a quaisquer leis que possam ser validamente criadas" (DWORKIN, 2016, p. 10-11). E não podemos perder de vista que os precedentes vinculantes têm, pela previsão constitucional, os mesmos efeitos que a lei formal e material. Logo, também em relação aos precedentes as normas constitucionais devem prevalecer, como meio de dar o sentido ao próprio direito.

Ainda nas palavras do filósofo (DWORKIN, 2016, p. 14), o método de "determinar o que diz o direito" deve guardar nexo com a "teoria geral do direito". Para a definição dessa teoria geral de direito, ele apresenta a necessidade de encontrar "uma exposição do conceito doutrinário de direito" como método para "determinar o que diz o direito". Segundo ele, a identificação desse conceito doutrinário de direito deve se dar em quatro estágios: semântico, teórico, doutrinário e da decisão judicial (DWORKIN, 2016, p. 15-32).

E o filósofo explicita que o julgador pode contrariar os termos da lei, em determinadas circunstâncias e em situações especiais.

A maioria das pessoas acredita que certos tipos de decisão política - em particular aquelas dos juízes que detém o monopólio do poder de coação do Estado - só devem ser tomadas quando necessários ou permitidos por proposições de direito verdadeiras. Para essas pessoas, isso configura uma restrição quase absoluta. Mas não se trata de algo tão absolutamente absoluto: elas admitem que em casos muito raros os juízes podem ter o dever moral de ignorar a lei quando esta for muito injusta ou, talvez, quando for muito insensata, e de usar seu poder político para impedir a injustiça ou uma grande ineficiência. Devemos, portanto, reconhecer um quarto estágio da análise jurídica: o nível da decisão judicial, em que se coloca a questão de saber o que autoridades políticas, das quais geralmente se espera que apliquem o direito, devem na verdade fazer em casos específicos. Trata-se, sem dúvida, de uma questão política e, consequentemente, também de uma questão moral. Não de uma questão sobre o modo como a moral figura na identificação do direito, mas sim de uma questão sobre quando, se é que alguma vez, a moral exige que os juízes atuem de modo independente da lei, ou mesmo que a contrariem. (DWORKIN, 2016, p. 28)

O entendimento esposado por Dworkin se encontra em consonância com o aqui adotado. É evidente que, vivendo em um Estado de Direito, a observância da lei e dos precedentes obrigatórios deve ser a rotina do julgador, até porque esta é a vontade da própria Constituição. Mas o império da lei também encontra exceção no ornamento, exceção essa que também alcança os precedentes obrigatórios.

A posição adotada por autores como Marinoni (2016, p. 3), de que a atribuição de sentido ao direito apenas é possível mediante precedentes obrigatórios e que esses devem ser adotados em todos os julgados, pois "o respeito aos precedentes é uma maneira de preservar valores indispensáveis ao Estado de Direito, assim como de viabilizar um modo de viver em que o direito assume a sua devida dignidade", não se opõe ao que neste artigo se sustenta. 
É evidente que este é bem maior perseguido pela jurisdição, pois sua atuação precípua é a de pacificar a sociedade através da aplicação do direito. Porém, encontraremos situações de exceção e, quando as encontrarmos, na solução do choque entre um precedente obrigatório editado em desconformidade com a Carta Magna, essa última deverá prevalecer. Não podemos esquecer que é indiscutível a prevalência dos direitos fundamentais, seja em face da lei, seja em face dos precedentes.

Claro que o nosso ordenamento processual prevê a necessidade de uniformização dos julgados dos Tribunais e a edição de precedentes obrigatórios. Também é claro que os princípios da segurança jurídica e da isonomia devem pautar a atuação dos órgãos julgadores. Mas daí a dizer que em todo e qualquer caso o precedente deve ser aplicado extrapola o sentido da nossa Constituição Federal, pois é do direito que a igualdade não se esgota na assertiva de que os diferentes devem ser tratados de forma igual.

A existência do instituto processual da Reclamação já deixa claro que a última resposta sobre a aplicação efetiva dos precedentes está nas mãos dos próprios Tribunais que exararam os precedentes em discussão. E na forma do artigo $8^{\circ}$ do Código de Processo Civil, essa análise do Tribunal de Precedentes também deverá ser pautada pela análise a partir da dignidade da pessoa humana.

\section{CONCLUSÃO}

A teoria da "força da lei", do positivismo jurídico clássico, vem sendo enfraquecida pela interpretação dada pelo Poder Judiciário Brasileiro em decisões judiciais prolatadas em obediência aos termos da Constituição Federal, ligadas à lógica do controle difuso e concentrado de constitucionalidade, tendo por centralidade a dignidade da pessoa humana.

O Código de Processo Civil de 2015 trouxe uma organização sistêmica para a aplicação dos precedentes judiciais, especialmente as regras dos artigos 927 e 928, que tratam, segundo boa parte da doutrina nacional, dos chamados precedentes obrigatórios, passando a ideia de que aqueles julgados lá mencionados terão força coercitiva objetiva para o Poder Judiciário como um todo, trazendo um novo paradigma para a racionalidade judicial. Porém, se não bastasse o complexo sistema jurídico, não se deve esquecer que o Brasil é país que se encontra em desenvolvimento $\mathrm{e}$, por isso, submetido às crises próprias de tal processo, inclusive quanto às contradições sociais e políticas de uma sociedade diferenciada.

Em um estado democrático de direito, para que se possa atender à lei (aqui apresentada como gênero, nos quais os precedentes se inserem) é indispensável que o Poder Judiciário aplique o ordenamento jurídico pátrio para manter a unidade e coerência, sempre que possível apresentando meios para que questões fáticas e idênticas recebam o mesmo tratamento. Mas havendo discrepância entre a lei referida e a Constituição Federal, deve prevalecer essa última.

A metodologia fuzzy e programas com utilização de inteligência artificial podem ser aplicados ou utilizados pelo Poder Judiciário em determinadas situações, quando se faz necessário o estabelecimento de um discurso baseado em levantamentos objetivos (ainda que o universo do discurso se apoie em termos vagos, indeterminados e incertos), sempre, porém, como forma de fixar graus ou limites, e não como instrumento de interpretação da lei ou precedentes obrigatórios, pois o direito é humano, e sua interpretação deve ser feita apenas pelos juízes que detenha essa humanidade (human judge).

Toda e qualquer decisão dada pelo Poder Judiciário na realização do processo justo, deverá respeitar o princípio constitucional da dignidade da pessoa humana, que foi transportado da Constituição para o novo Código de Processo Civil como norma processual concreta (artigo $8^{\circ}, \mathrm{CPC}$ ), permeando a obrigação constitucional do Estado de construir a efetividade dos direitos sociais, culturais e econômicos baseado nos anseios dos cidadãos, analisando condições 
subjetivas do caso concreto, à luz da própria humanidade, e não à luz da artificialidade, sob pena de gerar injustiça do caso concreto.

\section{REFERÊNCIAS}

ALVES, Fernando de Brito. Democracia à portuguesa:retórica democrática na tradição jurídica lusófona. Rio de Janeiro: Editora Lumen Juris, 2014.

ALVES, Henrique Napoleão. No Brasil há uma tradição de descaso no dever de fundamentar.Disponível em:https:/www.conjur.com.br/2017-out-11/henrique-alves-tradicaodescaso-dever-fundamentar.Acesso em 11 nov. 2017.

ALVIM, Teresa Arruda. Ativismo Judicial: A vinculatividade dos precedentes e o ativismo judicial- paradoxo apenas aparente.Disponível

em:http://emporiododireito.com.br/backup/tag/ativismo-judicial/. Acesso em 09 abr. 2018.

ANDRADE, José Maria Arruda de. Risco fiscal não é fundamento judicial válido para aumentar tributos.Disponível em: https://www.conjur.com.br/2017. Acesso em 09 out. 2017.

ARRETCHE, Marta. Democracia, federalismo e centralização no Brasil. Rio de Janeiro: Editora FGV/Editora Fiocruz: 2012.

BOBBIO, Norberto. Direito e Estado no Pensamento de Emanuel Kant. Tradução de Alfred Fait, 4 ed. Brasília: Editora Universidade de Brasília, 1997.

BREGA FILHO, Vladimir. Direitos Fundamentais na Constituição de 1988: conteúdo jurídico das expressões. São Paulo: Editora Juarez de Oliveira, 2002.

CAMBI, Eduardo. Jurisdição no processo civil: uma visão crítica. 5 ed. Curitiba: Juruá Editora, 2009.

CAMBI, Eduardo; FOGAÇA, Mateus Vargas. Sistema dos precedentes judiciais obrigatórios no Novo Código de Processo Civil. In: DIDIER JR., Fredie et al (Coord.). Precedentes. Salvador: Juspodivm, v. 3. (Coleção grandes temas do novo CPC), 2015.

CANOTILHO, José Joaquim Gomes. Metodologia ' $f u z z y$ ' y 'camaleones normativos' em la problemática actual de los derechos económicos, sociales y culturales. Coimbra: Derechos y Liberdades: Revista del Instituto Bartolomé de Las Casas; Universidade de Coimbra,1998.

CARNEIRO, Maria Francisca. Direito \& Lógica - Temas de Direito Perpassados pela Lógica. $4^{\text {a }}$ ed. Curitiba, Editora Juruá, 2013.

CAPPELLETTI, Mauro; GARTH, Bryant. Acesso à Justiça. Tradução Ellen Grace Northfleet: Porto Alegre: Sérgio Antônio Fabris Editor, 1998.

DILL, Rodrigo Prante. Análise da rentabilidade de Empresas: Uma abordagem baseada nalógica nebulosa (fuzzy logic). 2005. Dissertação (Mestrado em Administração) - Curso de Pós-Graduação em Administração, Universidade Federal de Santa Catarina, Florianópolis, 2005. Disponível em: https://repositorio.ufsc.br. Acesso em 01 abr. 2018. 
DWORKIN, Ronald. A Justiça de toga. São Paulo, Editora Martins Fontes, 2016.

FREITAS, Juarez de. Direito Fundamental à Boa Administração: São Paulo, Malheiros, 2014.

GARCIA, Emerson; ALVES, Rogeria Pacheco. Improbidade Administrativa. $6{ }^{\text {a }}$ ed. Rio de Janeiro: Lumen Juris, 2011.

HABERMAS, Jürgen. A inclusão do outro: estudos de teoria política. São Paulo: Edições Loyola, 2007.

HÖFFE, Otfried. Justiça política: fundamentação de uma filosofia crítica do Direito e do Estado. 3a. ed. Trad. Ernildo Stein. São Paulo: Martins Fontes, 2005.

MALAMAN, Carolina Scherrer. Aplicação de lógica fuzzy na elaboração de planta de valores genéricos. Presidente Prudente: tese de mestrado, UNESP, 2013. Disponível em: https://repositorio.unesp.br. Acesso em 01 abr. 2018.

MARINONI, Luiz Guilherme. Cultura e previsibilidade do direito. Rev. Trib. Sup. Trab-TST, Brasília, v. 80, n. 4, out./dez. 2014.

MARINONI, Luiz Guilherme. A ética dos precedentes: justificativa do novo CPC: São Paulo: Revista dos Tribunais, 2016.

MARTINS, Flademir Jerônimo Belinati. Dignidade da Pessoa Humana. Curitiba: Juruá, 2003.

MORO, Sérgio Fernando. Jurisdição constitucional como democracia. São Paulo: Editora Revista dos Tribunais, 2004.

MITIDIERO, Daniel. Precedentes: da persuasão à vinculação. São Paulo: Revista dos Tribunais, 2017.

PEREIRA, Alexandre Libório Dias. Ius ex machina? Da informática jurídica ao computador-juiz. Coimbra: Revista RJLB, ano 3 (2017), n. 1, p.46-126. Disponível em:

http://www.cidp.pt/publicacoes/revistas/rjlb/2017/1/2017. Acesso em: 03 abr. 2018.

RIBEIRO, Ana Paula Brandão. MIRANDA, Isabella Carolina. O processo constitucional e a proteção dos direitos fundamentais no Estado Democrático Brasileiro. Revista de Direito Brasileira. São Paulo, v. 14, n. 6, p. 139-157, mai/ago. 2016.

RIGNEL, Diego Gabril de Sousa et al. Uma introdução à lógica fuzzy. RESIGeT. v. 1, p 17-27, 2011. Disponível em:http://www.logicafuzzy.com.br.Acesso em 08 abr. 2018.

RODRIGUES, José Rodrigo. Como decidem as cortes? Para uma crítica do direito (brasileiro). Rio de Janeiro: FGV, 2013.

SCHEIFER, Camila E.; MANDALOZZO, Silvana S. N.; CAMPAGNOLI, Adriana de Fátima P. F. Judicialização da política no Brasil: o poder judiciário como guardião dos direitos fundamentais. Revista de Direito Brasileira. São Paulo, SP. v. 14, n. 6. p. 158-172, maio/ago. 2016. 
SCHAUER, Frederick. Thinking like a lawyer: a new introduction to legal reasoning. First Harvard University Press paperback edition, 2012.

SERBENA, Cesar Antonio. Aplicações da Informática Decisória ao Direito: lógica Fuzzy e redes neurais. in Derecho y tecnologias avanzadas/Pilar Lasala Calleja (ed.): Zaragoza, Prensas de La Universidad de Zaragoza, 2013.

SERRA JÚNIOR, Marcus Vinicius Barreto. A vinculação do precedente judicial e a segurança jurídica. RIL Brasília. Ano 54, n. 214, abr/jun, 2017, p.131-152.

SILVA, José Afonso. Curso de Direito Constitucional Positivo. São Paulo, $23^{\mathrm{a}}$ ed. Malheiros Editores, 2003.

SOMBRA, Thiago Luís Santos. Supremo Tribunal Federal representativo? O impacto das audiências públicas na deliberação.Revista da FVG, v. 13, n. 1, Jan-abr, 2017. Disponível em:http://www.scielo.br/pdf/rdgv/v13n1/1808-2432-rdgv-13-01-0236.pdf. Acesso: 01 jul. 2018.

SOUZA, Jorge Munhós. Diálogo Institucional e Direito à Saúde. Dissertação do Programa de Mestrado da UERJ - Universidade do Estado do Rio de Janeiro, 2011.

SOUZA NETO, Cláudio Pereira; SARMENTO, Daniel. Notas sobre jurisdição constitucional e democracia: a questão da "última palavra" e alguns parâmetros de autocontenção judicial.Revista Quaestio Iuris, v. 06, n. 02, p.119-161.

TOMÉ, Levi Rosa. Menos forma, mais Justiça: a necessária simplificação do processo. Rio de Janeiro: Editora Lumen Juris, 2014. 